\title{
EMPLOYEES' ENGAGEMENT ON HUMAN RESOURCE MANAGEMENT PRACTICE IN PUBLIC SECTOR BANKS OF PUDUKKOTTAI DISTRICT, TAMILNADU
}

\author{
Dr. K Punitha \\ Assistant Professor, PG and Research Department of Business Administration J.J. College of \\ Arts and Science (Autonomous), Pudukkottai, Tamilnadu, India
}

\begin{abstract}
The banking sector in India is therefore witnessing tremendous changes because of political, social and economic upheavals that are taking place domestically and internationally. The banking industry in India has undergone a radical change in the last two decades. Now the banking has become too open and competitive. The basic focus and direction has changed from a level of moderate business to a maximum possible limit. Even the flow of business movement has changed from Customer's door step to bankers, now from Banker's to customers' doorstep. At this backdrop, the study of human resource management practices and Employee Engagement are quite important for formulating sound polices for the future. Therefore, the study is lead by answering the research questions as is there any relationship between human resource management practices and Employee Engagement of the employees in the Indian banking sector? Hence, the present study aims to analyze the impact of human resource management practices and employee engagement in Indian banking Sector in the study area through the socio economic of employees.
\end{abstract}

Key words: Banking Industry, Human Resource Management, Employee Engagement and Socio Economic.

Cite this Article: K Punitha, Employees' Engagement on Human Resource Management Practice in Public Sector Banks of Pudukkottai District, Tamilnadu, International Journal of Management (IJM), 11(12), 2020, pp. 2994-3000.

http://iaeme.com/Home/issue/IJM?Volume $=11 \&$ Issue $=12$

\section{INTRODUCTION}

To thrive in today's highly competitive and often tumultuous economic environment, organizations must employ a workforce that is proactive as well as committed to performing at high standards, both at the individual and organizational level. Work engagement can provide organizations with a competitive advantage. Most notably, employers who are focused on 
building and maintaining an engaged workforce may experience beneficial outcomes such as increased business-unit performance, strong financial returns, and a positive corporate image. In addition, the crossover of engagement among members of the same work team may prove valuable for organizational performance. Given these advantages, organizations may want to implement programs that promote engagement as they may lead to positive outcomes in the form of retention and performance.

So the potential value of the employees needs to be increased by enhancing and linking skills and capabilities in tune with the contemporary requirements of the market. The human resource management is a function which is mainly concerned with people at work and with their relationship within the organization. It is the resource which plans, allocates and provides for all other resources in organizations.

Most of the organizations have sidelined the Human Resource Management function owing to lack of immense knowledge about the importance involved in the successful handling of that function. In this study an attempt has been made to assess the perception of employees of on the Human Resource Management practices and the level of Employee Engagement of employees of the public sector banks operating in Pudukkottai district of Tamil Nadu. Employees' perception and job satisfaction are essential factor for better service in public sector banks as they include the effectiveness and motivation. Hence the study has been initiated from the desire to study and measure the degree of employee perception and Employee Engagement in the public sector banks in Pudukkottai district and explore the various possibilities to improve them for the benefit of the Banks as well as employees

\section{NEED FOR THE STUDY}

In today's competitive business environment, a service organization depends more than ever on the efficient functioning of its most valuable resource, its employees. In recognition of this fact, a holistic approach to the understanding of employee attitudes is emerging in occupational health psychology (OHP) specifically employee well being. This holistic approach extends beyond simple measurement of job satisfaction and job performance, moving toward an integrated strategy of organizational behavior known as "healthy workplace practices." The healthy workplace can be defined as any organization that maximizes the integration of employee goals for his or her well-being along with company objectives for profitability and productivity. Empirical links have been demonstrated between healthy workplace practices and employee engagement through the social economics status of employee.

\section{STATEMENT OF THE PROBLEM}

Banking sector in India has undergone tremendous change in its operations in the last decade. Owing to a highly competitive scenario; it is pertinent to note that banks need to differentiate themselves from each other. They need to have employees who are passionate about their work and strive to take their organization to greater heights for which employee wellness is essential. Firms should consider that well developed human resource practice is best to improve the employee engagement in the organization. Human resources form the knowledge asset of an organization. Along with products and services, these knowledge employees provide a source of competitive advantage to the organization. Attracting, motivating and retaining them have been the constant Endeavour of management. In this process, an effort is made to create an environment that supports employee's career aspiration. A meaningful job and career prospects can provide employees a sense of satisfaction. Satisfied employees create satisfied customers. In the long run, an environment is required to enhance the state of wellness and satisfaction to engagement. Therefore, the study is lead by answering the research questions as is there any relationship between human resource management practices and Employee Engagement of the 
employees in the Indian banking sector? Hence, the present study aims to analyze the impact of human resource management practices and employee engagement in Indian banking Sector in the study area through the socio economic of employees.

\section{RESEARCH PLAN}

Pudukkottai District was purposively selected for the study. It is one of the developing districts of the state of Tamil Nadu.

The primary data required for the study was collected from the employees using wellstructured and elaborate questionnaire. The questionnaire method is used. To measure the sources of employee engagement, human resource practice and socio economic status of employee in public sector bank in Pudukkottai district. These variables were scored on an interval Likert-type scale. The sample size was 247 . The significance of the $r$ values was tested for 5 per cent levels. Chi Square tests was calculated to find out the degree of relationship between Level of satisfaction of the employees about effectiveness of human resources management practices and relationship with the socio economic variables such as age, gender, education, designation, and years of experience and annual income of the employees.

\section{RESEARCH OBJECTIVES}

The specific objective of the study is;

- To assess the level of Employee Engagement among the employees of the study units.

- To study the relationship between the Socio Economic variables and Employee Engagement of employees in the study area.

\subsection{Hypothesis}

H01: Level of satisfaction of the employees about effectiveness of human resources management practices has no significant relationship with the socio economic variables such as age, gender, education, designation, and years of experience and annual income of the employees.

\section{ANALYSIS AND DISCUSSION}

\subsection{Satisfaction of Employees Relating to Their Work Load}

Table 1 Chi Square Test for Level of Satisfaction on Work Load Vs Socio Economic variables

\begin{tabular}{|c|l|c|c|c|}
\hline S.No & \multicolumn{1}{|c|}{$\begin{array}{c}\text { Association between } \\
\text { Work Load }\end{array}$} & $\begin{array}{c}\text { Pearson } \\
\text { Chi- Square }\end{array}$ & $\begin{array}{c}\text { Degrees of } \\
\text { freedom }\end{array}$ & P value \\
\hline 1 & Age & 11.877 & 6 & .065 \\
\hline 2 & Gender & 1.728 & 2 & .421 \\
\hline 3 & Education & 4.507 & 4 & .342 \\
\hline 4 & Designation & 1.608 & 4 & .807 \\
\hline 5 & Experience. & 4.573 & 6 & .600 \\
\hline 6 & Annual income & 7.286 & 6 & .295 \\
\hline
\end{tabular}

Source: Primary Data \& Output generated from SPSS 21

Relationship between the Socio Economic Variables such as age, gender, education, designation, experience and annual income of the employees and their Satisfaction relating to their work load have been analyzed. The results are presented above in Table.1. Since all the $p$ 
values are higher than 0.05 , Null hypotheses relating to all the socio economic variables are accepted and inferred that the level of satisfaction of employees relating to the work Load has no significant relationship with any of the socio economics variables, viz., age, gender, education, designation, experience or annual income.

\subsection{Satisfaction of Employees Relating to Supervision}

Table 2 Chi Square Test for Level of Satisfaction on Supervision Vs Socio Economic variables

\begin{tabular}{|c|l|c|c|c|}
\hline S.No & $\begin{array}{c}\text { Association between } \\
\text { Supervision }\end{array}$ & $\begin{array}{c}\text { Pearson } \\
\text { Chi- Square }\end{array}$ & $\begin{array}{c}\text { Degrees of } \\
\text { freedom }\end{array}$ & p value \\
\hline 1 & Age & 2.843 & 6 & .828 \\
\hline 2 & Gender & .321 & 2 & .852 \\
\hline 3 & Education & 1.650 & 4 & .800 \\
\hline 4 & Designation & 2.027 & 4 &. .731 \\
\hline 5 & Experience. & 4.766 & 6 & .574 \\
\hline 6 & Annual income & 1.442 & 6 & .963 \\
\hline
\end{tabular}

Source: Primary Data \& Output generated from SPSS 21

Relationship between the Socio Economic Variables such as age, gender, education, designation, experience and annual income of the employees and their Satisfaction relating to Supervision have been analyzed .The results are presented above in Table. 2. Since all the $p$ values are higher than 0.05 , Null hypotheses relating to all the socio economic variables are accepted and inferred that the level of satisfaction of employees relating to the supervision has no significant relationship with any of the socio economics variables, viz., age, gender, education, designation, experience or annual income.

\subsection{Satisfaction of Employees Relating to Pay}

Table 3 Chi Square Test for Level of Satisfaction on Pay Vs Socio Economic variables

\begin{tabular}{|c|l|c|c|c|}
\hline S.No & Association between Pay & $\begin{array}{c}\text { Pearson } \\
\text { Chi- Square }\end{array}$ & $\begin{array}{c}\text { Degrees of } \\
\text { freedom }\end{array}$ & p value \\
\hline 1 & Age & 10.338 & 9 & .324 \\
\hline 2 & Gender & .999 & 3 & .801 \\
\hline 3 & Education & .783 & 6 & .250 \\
\hline 4 & Designation & 11.328 & 6 & .079 \\
\hline 5 & Experience. & 13.415 & 9 & .145 \\
\hline 6 & Annual income & 15.373 & 9 & .081 \\
\hline
\end{tabular}

Source: Primary Data \& Output generated from SPSS 21

Relationship between the Socio Economic Variables such as age, gender, education, designation, experience and annual income of the employees and their Satisfaction relating to Pay have been analyzed.The results are presented above in Table.3. Since all the $p$ values are higher than 0.05 , Null hypotheses relating to all the socio economic variables are accepted and inferred that the level of satisfaction of employees relating to Pay has no significant relationship with any of the socio economics variables, viz., age, gender, education, designation, experience or annual income.

\subsection{Satisfaction of Employees Relating to Promotion}


Employees' Engagement on Human Resource Management Practice in Public Sector Banks of Pudukkottai District, Tamilnadu

Table 4 Chi Square Test for Level of Satisfaction on Promotion Vs Socio Economic variables

\begin{tabular}{|l|l|c|c|c|}
\hline S.No & \multicolumn{1}{|c|}{$\begin{array}{c}\text { Association between } \\
\text { Promotion }\end{array}$} & $\begin{array}{c}\text { Pearson } \\
\text { Chi- Square }\end{array}$ & $\begin{array}{c}\text { Degrees of } \\
\text { freedom }\end{array}$ & p value \\
\hline 1 & Age & 4.932 & 6 & .553 \\
\hline 2 & Gender & .060 & 2 & .970 \\
\hline 3 & Education & 9.752 & 4 & .045 \\
\hline 4 & Designation & 3.115 & 4 & .539 \\
\hline 5 & Experience. & 1.736 & 6 & .942 \\
\hline 6 & Annual income & 2.401 & 6 & .879 \\
\hline
\end{tabular}

Source: Primary Data \& Output generated from SPSS 21

Relationship between the Socio Economic Variables such as age, gender, education, designation, experience and annual income of the employees and their Satisfaction relating to Distribution of Respondents by their level of Employee Engagement relating to Promotion have been analyzed. The results are presented above in Table. 4. Education of the respondents has significant relationship with the level of satisfaction on promotion. All other $p$ values are higher than 0.05 , Null hypotheses relating to all the socio economic variables, except education, are accepted and inferred that the level of satisfaction of employees relating to Distribution of Respondents by their level of Employee Engagement relating to Promotion has no significant relationship with the socio economics variables, viz., age, gender, designation, experience or annual income.

\subsection{Satisfaction of Employees Relating to Co - Workers}

Table 5 Chi Square Test for Level of Satisfaction on Co - workers Vs Socio Economic variables

\begin{tabular}{|c|l|c|c|c|}
\hline S.No & $\begin{array}{c}\text { Association between Co - } \\
\text { workers }\end{array}$ & $\begin{array}{c}\text { Pearson } \\
\text { Chi- Square }\end{array}$ & $\begin{array}{c}\text { Degrees of } \\
\text { freedom }\end{array}$ & p value \\
\hline 1 & Age & 15.842 & 12 & .199 \\
\hline 2 & Gender & 1.381 & 4 & .848 \\
\hline 3 & Education & 5.916 & 8 & .657 \\
\hline 4 & Designation & 8.266 & 8 & .408 \\
\hline 5 & Experience. & 12.524 & 12 & .405 \\
\hline 6 & Annual income & 12.352 & 12 & .418 \\
\hline
\end{tabular}

Source: Primary Data \& Output generated from SPSS 21

Relationship between the Socio Economic Variables such as age, gender, education, designation, experience and annual income of the employees and their Satisfaction relating to co-workers have been analyzed. The results are presented above in Table.5. All the $p$ values are higher than 0.05 , Null hypotheses relating to all the socio economic variables, are accepted and inferred that the level of satisfaction of employees relating to co-workers has no significant relationship with the socio economics variables, viz., age, gender, Education, designation, experience or annual income.

\subsection{Overall Employee Engagement of Respondents}


Table 6 Chi Square Test for Level of Overall Satisfaction Vs Socio Economic variables

\begin{tabular}{|c|l|c|c|c|}
\hline S.No & $\begin{array}{c}\text { Association between } \\
\text { Overall Satisfaction }\end{array}$ & $\begin{array}{c}\text { Pearson } \\
\text { Chi- Square }\end{array}$ & $\begin{array}{c}\text { Degrees of } \\
\text { freedom }\end{array}$ & p value \\
\hline 1 & Age & 3.974 & 6 & .680 \\
\hline 2 & Gender & 2.036 & 2 & .361 \\
\hline 3 & Education & 3.876 & 4 & .423 \\
\hline 4 & Designation & 2.208 & 4 & .698 \\
\hline 5 & Experience. & 2.586 & 6 & .859 \\
\hline 6 & Annual income & 4.057 & 6 & .669 \\
\hline
\end{tabular}

Source: Primary Data \& Output generated from SPSS 21

Relationships between the Socio Economic Variables such as age, gender, education, designation, experience and annual income of the employees and their overall Satisfaction have been analyzed. The results are presented above in Table.6. All the $p$ values are higher than 0.05 , Null hypotheses relating to all the socio economic variables, are accepted and inferred that the level of overall Satisfaction has no significant relationship with the socio economics variables, viz., Age, Gender, Education, Designation, Experience and Annual income.

\section{CONCLUSION}

Human Resources Practices leads to the better perception of employees and hence improve the Employee Engagement. A positively perceived employee will contribute more with enthusiasm and engagement. Human Resources Management in Public sector banks is much more important than any in other manufacturing organization as they serve the common public where more involvement and service mind of employees are needed. Performance of the satisfied employees of the public sector banks leads them towards profitability and better business outcomes. This study has brought out the level of Employee Engagement of employees on five dimensions such as Work, Supervision, Pay, Promotion and Co-workers attitude were assessed through this study. Level of overall satisfaction was assessed using five levels viz., very low level, low level, moderate level, highly satisfied, very highly satisfied etc. Proportion of respondents expressed moderate or low satisfaction is high. The findings of the study will be useful for the public sector banks in shaping up their future policies relating to Human Resources Management.

\section{SUGGESTIONS}

Owing to a highly competitive scenario; it is pertinent to note that banks need to differentiate themselves from each other. The Public Sector Bank should improve human resource practices like Career development programme. Innovative training due to technological development, leadership development programme, team building practices to be implemented in Public sector banks can improve the level of employee engagement.

\section{REFERENCES}

[1] Aselstine, K., \& Alletson, K. (2006). A new deal for 21st century workplace. Retrieved May 25, 2010, from Ivey Business Journal: www.iveybusinessjournal.com 
Employees' Engagement on Human Resource Management Practice in Public Sector Banks of Pudukkottai District, Tamilnadu

[2] Biggs, A., Brough, P., \& Barbour, J. P. (2014). Relationships of individual and organizational support with engagement: Examining various types of causality in a three-wave study. Work \& Stress: An International Journal of Work, Health and Organisations, 236-254.

[3] Buckingham, M., \& Coffman, C. (1999). First Break All the Rules: What the World's Greatest Managers Do Differently. New York: Simon \& Shuster.

[4] Coffman, C., \& Gonzalez-Molina, G. (2002). Follow this path: How the world's greatest organizations derive growth by unleashing human potential. New York: Warner Books, Inc.

[5] Fisher, C. D., \& Locke, E. A. (1992). The New Look in Employee Engagement Research and Theory. In C. J. Cranny, P. C. Smith, \& E. F. Stone (Eds.), Employee Engagement : How People Feel about their Jobs and How It Affects Their Performance. NY : Lexington Books.

[6] Gruman, J. A., \& Saks, A. M. (2011). Performance Management and Employee Engagement. Human Resource Management Review , 21 (2), 123-136.

[7] Ketter, P. (2008). What's the big deal about employee engagement . Training and Development , 44-49.

[8] Merrill, R., Aldana, S. G., Pope, J. E., Anderson, D. R., Coberley, C. R., Grossmeier, J. J., et al. (2013). Self-Rated Job Performance and Absenteeism According to Employee Engagement, Health Behaviours and Physical Health. Journal of Occupational \& Environmental Medicine, 55 (1), 10-18.

[9] Shuck, B., \& Wollard, K. (2008). Employee engagement: Motivating and connecting with tomorrow's workforce. New horizons in Adult Education and Human Resource Development, $22(1), 48-53$.

[10] Fadi El-Jardali, et.al., Assessment of human resources management practices in Lebanese hospitals, journal of Human Resources for Health 2009, 7:84

[11] Garcia, M., Training and business performance: The Spanish case. International Journal of Human Resource Management, Vol.16, pp.1691-1710, 2005.

[12] Garry A. Gelade, The Impact of Human Resource Management and Work Climate on Organizational Performance, Personnel Psychology 2003, 56, 383-404.

[13] Junaid Zafar, Muhammad Shaukat and Norazuwa Mat "An Analysis of E-Human Resource Management Practices: A Case Study of State Bank of Pakistan" European Journal of Social Sciences - Volume 15, Number 1 (2010).

[14] Jyotsna Bhatnagar and Anuradha Sharma The Indian perspective of strategic HR roles and organizational learning capability, International of Journal of Human Resource Management 16:9 September 2005 1711-173.

[15] Karthikeyan , Dr. K. and R.Karthi, Impact of Training in Indian Banking Sector - An Empirical Investigation, International Journal of Business and Management Vol. 5, No. 7; July 2010

[16] Schuler R.S \& Jackson, S.E. (1987), Linking Competitive Strategies with Human Resources Management Practices, The Academy of Management Executives, 3. 207-219.

[17] Veeri Chettiar Arumugam, et.al., The Impact of Human Resource Management Practices on Financial Performance of Malaysian Industries, Australian Journal of Basic and Applied Sciences, 5(10): 951-955, 2011 